\title{
オーステナイト系ステンレス鋼の水蒸気酸化に およほす結晶粒度の影響*
}

\section{小 若 正 倫 ${ }^{* *}$ 永 田 三 郎**}

Masamichi Kowaka and Sabro Nagata : Effect of Grain Size on Oxidation of Austenitic Stainless Steels in Steam.

The oxidation of commercial austenitic stainless steels for boiler superheater tubes has been investigated in steam at a temperature range of $600^{\circ} \sim$ $650^{\circ} \mathrm{C}$. The results obtained are as follows :

(1) The oxidation rate of austenitic stainless steels decreased with time and increased with temperature.

(2) The oxidation rate of austenitic stainless steels in steam, was greatly affected by the grain size of the steels. The grain size of the steels was inversely related to the oxidation in steam, and it was explained by the formation of a protective $\mathrm{Cr}_{2} \mathrm{O}_{3}$ film due to the accelerated diffusion of chromium in the grain boundaries.

(3) The thickness of scale on the surface was proportional to the amount of oxidation in steam, and the outer scale was spalled off after growing to a definite thickness.

(4) The grinding of the metal surface reduced considerably the oxidation rate in steam.

(5) The rate of oxidation in steam was markedly greater than that in air.

(6) Electron microprobe analysis of the austenitic stainless steels oxidized in steam showed the distribution of $\mathrm{Fe}, \mathrm{Ni}, \mathrm{Cr}$ and $\mathrm{O}_{2}$ in the scale. The outer layer was composed of both $\alpha-\mathrm{Fe}_{2} \mathrm{O}_{3}$ and $\mathrm{Fe}_{3} \mathrm{O}_{4}$, the inner layer being of the spinel type containing ( $\mathrm{Fe}, \mathrm{Ni}, \mathrm{Cr}$ ) oxides.

(Received January 31, 1972)

\section{I. 緒 言}

オーステナイト系ステンレス鋼の過熱水蒸気による酸化 についての研究は比較的新しく, 火力発電用ボイラおよび 原子力発電用の過熱器管として使用する場合の問題として 研究されている.

最近我国においては事業用ボイラの過熱器管として使用 されているオーステナイト系ステンレス鋼の内面にスケー ルが生成し，熱伝達の低下，管壁温度の上昇, 㔀離スケ一 ルのタービンへの飛散, あるいはベンド部への堆積などに よる弊害が生じている.

現用オーステナイト系ステンレス鋼の耐水蒸気酸化性の 優劣については研究されてはいるが, その結果は著者 ${ }^{(1) \sim(4)}$ によりまちまちである. Ruther ら(1)(2) は水蒸気酸化にお よぼす各種要因について詳細な研究を行ない一連の報告 をしている. Warzee ら ${ }^{(5)}$ は酸洗, 研摩など水蒸気酸化に およぼす表面仕上げの影響について調べ，グラインダー研 摩は耐水蒸気酸化性を向上するが，高温水中ではその効果

** 住友金属工業株式会社中央技術研究所 (Central Research Laboratories, Sumitomo Metal Industries, Ltd., Amagasaki)

* 1971 年 4 月本会東京大会に発表：水蒸気酸化に関す る研究 (第 1 報)

(1) W.E. Ruther and S.Greenberg: J. Electrochem. Soc., 111 (1964) , 1116.

(2) W.E.Ruther, R.R.Schlueter, R.H.Lee and R.K. Hart : Corrosion, 22 (1966), 147.

(3) F. Eberle and C.H.Anderson : Trans.ASME, J. Engr. Power, (1962), 223.
は逆転することを報告している. Jansson ら ${ }^{(6)}$ は表面仕上 ゲの影響は $650^{\circ} \mathrm{C}$ までで，さらに高温になるとその効果 は滅少すると述べている。 スケールの構造については,

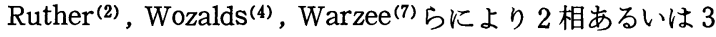
相になっていることが報告されている.

著者らは問題解決の手掛りを得るために現用ステンレス 鋼の水蒸気酸化におよぼす各種要因について研究を行な い，特に結晶粒度の影響およびそれに関連したスケールの 單離性について明らかな傾向を見出したので報告する.

\section{II. 実 験 方 法}

\section{1. 供 試 材}

水蒸気酸化試験に用いた材料は現用のオーステナイト系 ステンレス鋼 4 種類である. 化学成分を Table 1 亿示す.鋼 種の比較の場合は，これらの鋼管を $34^{\phi} \times 10^{l} \times 3.0^{l}$ 飞切 断し, 両端面のみ 280 メッシュのエメリー紙で研摩し， ア セトンで脱脂後試験に供した。一方結晶粒度の影響を調べ るためには，鋼管を綐割り，扁平にし， $1050^{\circ} \mathrm{C} \times 30 \mathrm{~min}$ 焼鈍後 $5,30 \%$ RA の加工をあたえ $10^{w} \times 30^{l} \times(2.1 \sim 2.8)^{t}$

(4) G. P. Wozalds and W. L. Pearl : Corrosion, 21 (1965) , 355.

(5) M.Warzee, J.Hennaut, M.Maurice, C.Sonnen and J.Waty : J.Electrochem. Soc., !12 (1965) , 670.

(6) S. Jansson, W. Hübner, G. Östberg and M. de Pourbaix : Br. Corrosion J., 4(1969), 21.

(7) M.Warzee, W.R. Ruston, P.de Dorlodot, J.Hennaut and P.H.Berge : Proc. 3rd International Congress on Metallic Corrosion, Moscow, (1966), 391. 
Table 1 Chemical composition of commercial stainless steels (wt \%)

\begin{tabular}{c|c|c|c|c|c|c|c|c|c|c|c|c}
\hline \hline Steel & G.S.* & $\mathrm{C}$ & $\mathrm{Si}$ & $\mathrm{Mn}$ & $\mathrm{P}$ & $\mathrm{S}$ & $\mathrm{Cu}$ & $\mathrm{Ni}$ & $\mathrm{Cr}$ & $\mathrm{Mo}$ & $\mathrm{Ti}$ & $\mathrm{Nb}$ \\
\hline $304 \mathrm{H}$ & 6.6 & 0.09 & 0.60 & 1.57 & 0.025 & 0.006 & 0.08 & 10.40 & 18.60 & 0.06 & - & - \\
$316 \mathrm{H}$ & 5.9 & 0.07 & 0.59 & 1.81 & 0.026 & 0.005 & 0.27 & 13.60 & 16.80 & 2.21 & - & - \\
$321 \mathrm{H}$ & 5.8 & 0.07 & 0.60 & 1.77 & 0.023 & 0.006 & 0.08 & 10.90 & 17.80 & - & 0.45 & 0.67 \\
$347 \mathrm{H}$ & 8.4 & 0.07 & 0.58 & 1.72 & 0.022 & 0.005 & 0.07 & 12.40 & 17.80 & - & - & 0.67 \\
\hline
\end{tabular}

の試験片に切断し再び $1000^{\circ}$ あるいは $1150^{\circ} \mathrm{C} に て ~ 15 \mathrm{~min}$ 焼鈍し結晶粒度を調整したものを作り試験に先立ち酸洗し た.

\section{2. 実験方法}

実験装置は Fig.1 に示す. 試験炉は $110^{\phi} \times 1000^{l}$ の二ク ローム線炉で，その中に $90^{\phi} \times 450^{l}$ のステンレス製鋼管を 插入しこれを試験室とした，室内に試験片を吊した後に両

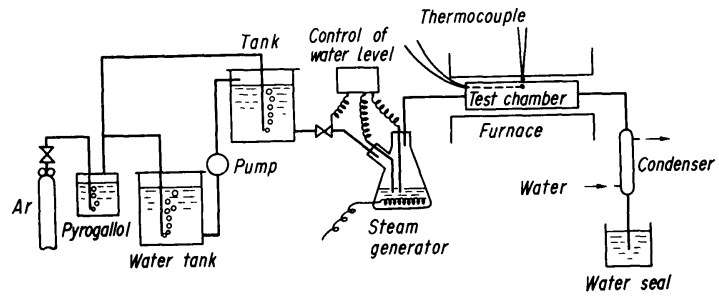

Fig.1 Apparatus for high temperature oxidation in steam at atmosphric pressure

端を封じ細管を連結した．試験室の中央部分 $250 \mathrm{~mm}$ の 範囲は $600 \pm 5^{\circ} \mathrm{C}$ に保たれるよらに調整されている. 水 は脱気槽中にて純化されたアルコンにより脱酸素され溶存 酸素 $0.1 \mathrm{ppm}$ 以下にし $60 \mathrm{~L}$ の給水槽に導かれて保管され る.ささらに，その水を導管にてフラスコに導き加熱沸騰し た.フラスコ内の液面は電磁バルブにより常に一定に保た れるように制御し, 発生した蒸気は予熱後試験室に導き, その後コンデンサーにて冷却凝縮した. 凝縮水量は $200 \mathrm{cc}$ /hr になるよらに蒸気発生用のヒーターの加熱により調整 した.

試験片は試験温度 $600^{\circ} \sim 650^{\circ} \mathrm{C}$, 試験時間 $500 \sim 2000 \mathrm{hr}$ に保持した後に試験室より取り出し $\mathrm{NaOH}+\mathrm{KMnO}_{4}$ 溶液 にて脱スケール後重量測定を行なった。 また同時に断面の 顕微鏡観察，EPMA，スケールの分析等も行なった。

スケール残留率の表示は, 酸化減量で示されるむのはす ベてマグネタイトが生成したと仮定して次の式で計算し た.

$$
\begin{aligned}
& \text { スケール残留率 }=\{0.724(\mathrm{~B}-\mathrm{C}) /(\mathrm{A}-\mathrm{C})\} \times 100 \\
& \text { ただし } \mathrm{A}: \text { 試験前重量 } \mathrm{B}: \text { 試験後重量 } \\
& \mathrm{C}: \text { 脱スケール後重量 } .
\end{aligned}
$$

\section{III. 実 験 結 果}

水蒸気酸化におよぼす要因のらち, 試験温度, 時間, 表面 仕上げ，結晶粒度等の影響について調べた結果を述べる.

\section{1. 試験温度, 試験時間の影響}

Fig. 2 に現用ステンレス鋼の $650^{\circ} \mathrm{C} に お け る$ 水蒸気酸 化減量と試検時間の関係を示す．図から 347 鋼が最も水蒸 気酸化減量が少なく，316 鋼が大きい，そして 304,321 鋼 はその中間に位する。各鋼種とも $1000 \mathrm{hr}$ までは急速に酸 化が進行するが，それ以後は酸化速度が減少する傾向にな る.ただし， 316 鋼のみは酸化は時間と共に増大する。

Fig. 3 は水蒸気酸化におよぼす温度の影響を示したもの で, 試験温度 $600^{\circ} \sim 650^{\circ} \mathrm{C}$ の範囲で $1000 \mathrm{hr}$ 保持後の酸 化減量を求めた。図より鋼種による耐水蒸気酸化性は, Fig. 2 と全く同様である．温度による影響としては $650^{\circ} \mathrm{C}$ より水蒸気酸化が著しくなるようである。

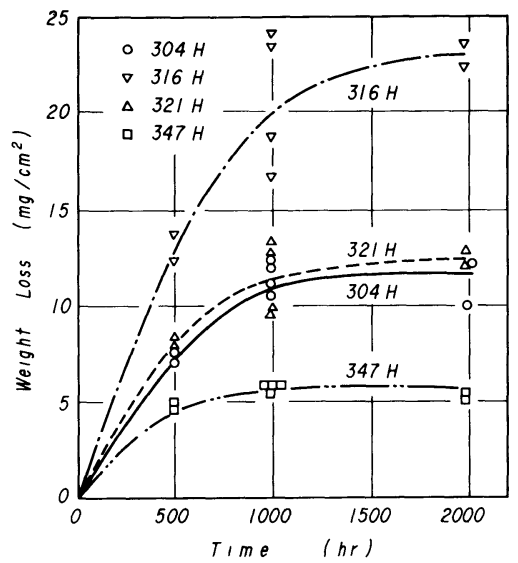

Fig.2 Effect of duration on oxidation in steam of commercial stainless steels at $650^{\circ} \mathrm{C}$

Fig. 4 は試験後に試験片表面に残留しているスケール量 と温度の関係を示したものである．残留率 $100 \%$ というこ とは生成スケールがほとんど䟝離しないでそのまま付着し ていることを示し，50\%といらことは，外層と内層はほぼ 同量生成 ${ }^{(8)}$ するので外層が汪とんど䟝離したことを意味す る.したがって 347 鋼のように酸化減量の少ない材料はス ケールもほとんど䟝離しないで残存しており，316 鋼のよ らに酸化減量の大きい材料は残留スケールも50\%近い値 を示し，外層はほとんど㓥離していることがわかる，そし て試験温度の上昇と共に残留率は小さくなる.

\section{2. 結晶粒度の影敏}

水蒸気酸化におよぼす結晶粒度の影響を明らかにするた (8) T.Ericsson : Oxidation of Metals, 2(1970) , 173. 


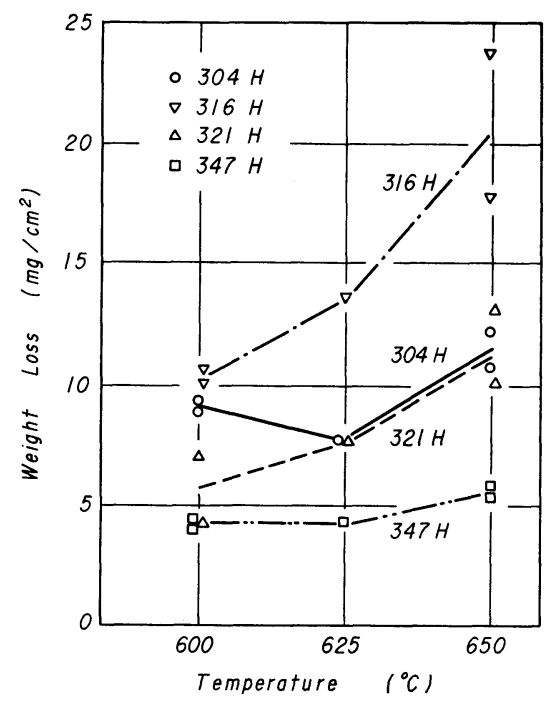

Fig.3 Effect of testing temperature on oxidation in steam of commercial stainless steels for $1000 \mathrm{hr}$

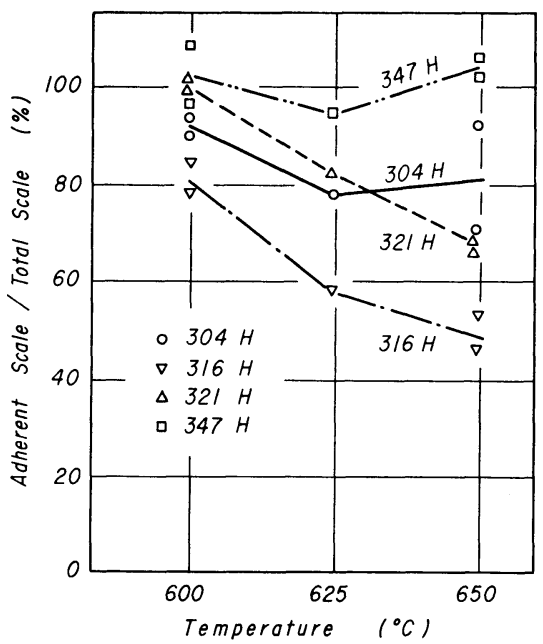

Fig.4 Effect of testing temperature on the amount of adherent scale formed in steam for $1000 \mathrm{hr}$

めに, Table 1 に示す材料の冷間加工度, 加熱温度, 拈よ び加熱時間を変えて結晶粒度を ASTM No. 2〜9 の範囲に 調整し, 水蒸気酸化試験を行なった。 それらの結果を,

Fig.5 に示す。図中黒印は結晶粒度を調整したもので，白 印は現用鋼管そのままである。これより鋼種による差異は 比較的少なく, 結晶粒度依存性が大きいことが明らかであ る. 現用 347 鋼管が著しく耐水蒸気酸化性がすぐれていた のは困中口印で示されているように結晶粒度が非常に細か く ASTM No. 8.4 であるためと考兄られる. 347 鋼でも結 晶粒度を大きくしてASTM No. 2.5 にすると著しく水蒸気 酸化性が増大する．また結晶粒度が同程度であるときは， 化学成分の差による水蒸気酸化性の差が認められる. たと えば ASTM No. 5.8〜6.0 に打ける 321，316 鋼の場合で ある。

Fig.6にはスケールの残留率を示す.すなわち，スケー

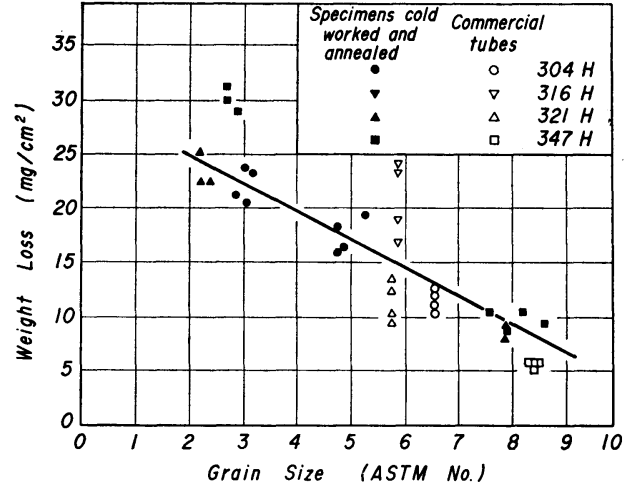

Fig.5 Effect of grain size on oxidation in steam of austenitic stainless steels at $650^{\circ} \mathrm{C}$ for $1000 \mathrm{hr}$

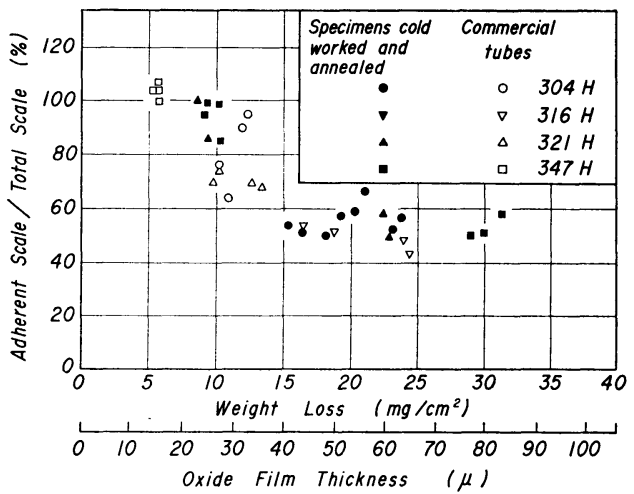

Fig.6 Relation between adherent scale formed in steam and weight loss (oxide film thickness), $\left(650^{\circ} \mathrm{C}, 1000 \mathrm{hr}\right)$

ルの厚さがある一定値以上に成長すると䟝離がはじまる. その值は約 $30 \mu$ 位であろう. 酸化量の増大とともに残留 率 50\%に近づき，ほとんど外層が虽離してしまらことが わかる.

Photo.1 亿一部の顕微鏡観察結果を示す．結晶粒度の大 小により酸化スケール量が異なり, 且つスケールは 2 層構 造をしていることが見られる。そして酸化は粒界よりも粒 内の方が進行している．また結晶粒度の大きい試験片では 外層と内層と比較すればわかるように，多くの場合外層は 䐣離しているが，このように，一部残存していることすあ る. しかしそれらの境界に割れができて刑離する直前の状 態であると考えられる．これに反し結晶粒度の小さい試験 片では外層と内層とほぼ同じ厚さに発達している.

\section{3. 表面仕上げの影篭}

水蒸気酸化におよぼす表面仕上げの影響を調べるために 現用 4 鋼種の短冊型試験片を $1100^{\circ} \mathrm{C} \times 30 \mathrm{~min}$ 焼鈍後, 酸 洗 (硝弗酸), エメリ一研摩(\#0), グラインダー研摩など 行なった後に $650^{\circ} \mathrm{C} \times 500 \mathrm{hr}$ 水蒸気酸化試験を行なった。 結果を Table 2 に示す。これよりグラインダー研摩のよ らに表面に強加工を受けている場合は, 他の表面仕上げの ものに比較して水蒸気酸化が著しく小さいことがわかる. 


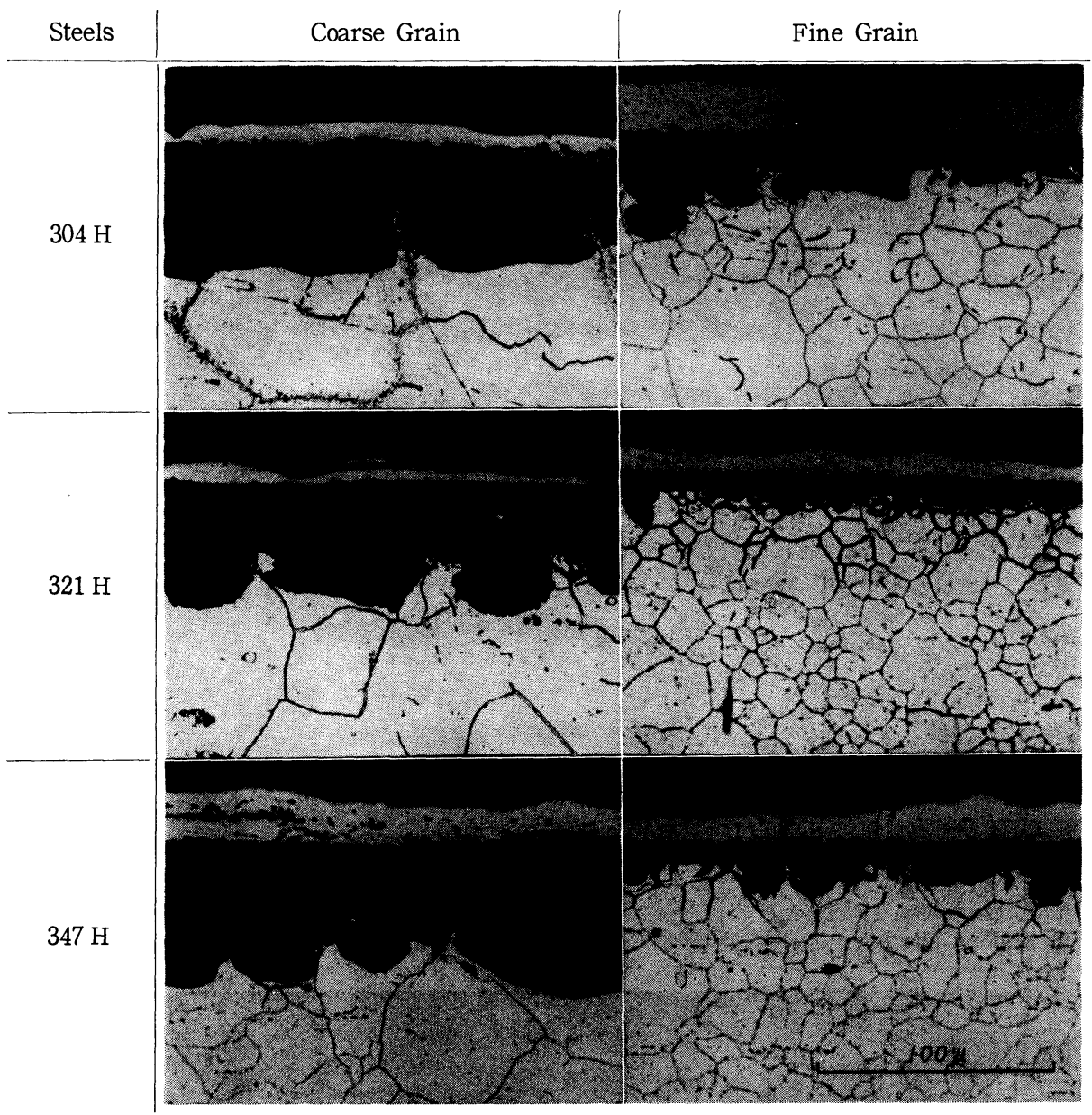

Photo.1 Microstructures of oxide formed by oxidation in steam at $650^{\circ} \mathrm{C}$ for $1000 \mathrm{hr}$

Table 2 Effect of mechanical polish on oxidation in steam at $650^{\circ} \mathrm{C}$ for $1000 \mathrm{hr}$ (weight $10 \mathrm{ss}, \mathrm{mg} / \mathrm{cm}^{2}$ )

\begin{tabular}{c|c|c|c|c|c|c|c|c|c}
\hline \hline \multirow{2}{*}{ Preparation } & \multicolumn{3}{|c|}{ Acid pickled } & \multicolumn{3}{c|}{ Emery } & \multicolumn{3}{c}{ Mechanical polish } \\
\hline Steel & 1 & 2 & Avr. & 1 & 2 & Avr. & 1 & 2 & Avr. \\
\hline $304 \mathrm{H}$ & 23.60 & 25.40 & 24.50 & 7.57 & 5.17 & 6.37 & 0.52 & 0.28 & 0.40 \\
$316 \mathrm{H}$ & 26.82 & 20.10 & 23.46 & 8.10 & 8.70 & 8.40 & 3.88 & 3.56 & 3.72 \\
$321 \mathrm{H}$ & 25.52 & 26.29 & 25.91 & 0.36 & 0.37 & 0.37 & 0.23 & 0.26 & 0.52 \\
$347 \mathrm{H}$ & 15.88 & 19.47 & 17.68 & 9.57 & 3.46 & 6.52 & 0.29 & 0.64 & 0.47 \\
\hline
\end{tabular}

304 鋼の顕微鏡観察結果を Photo. 2 に示す. 酸洗仕上げ のものは水蒸気酸化が著しく, 外層は㕷離し内層のみ残っ ている. グラインダー研摩の場合は, 研摩層が残存してお り，ほとんど酸化層がみられない位である。

\section{4. スケールの構造}

304 型ス㑔鋼を $600^{\circ} \mathrm{C} \times 1000 \mathrm{hr}$ 水蒸気酸化試験 を行なった後の断面の顕微鏡写真を Photo. 3 に示す。 ス ケールは 2 層構造をなし, 外層は多孔質で酸化鉄を主体と する $\alpha-\mathrm{Fe}_{2} \mathrm{O}_{3}$ と $\mathrm{Fe}_{3} \mathrm{O}_{4}$ より成り, 内層は $\mathrm{Fe}, \mathrm{Ni}, \mathrm{Cr}$ のス ピネル型酸化物である、虽離は内外層の境界よりおこり, 䟝離スケールの分析結果はほとんど鉄酸化物で, $\mathrm{Ni}, \mathrm{Cr}$ は $1 \%$ 以内しか含まれていない.
Photo.4 は水蒸気酸化試験後の X 線マイクロアナライザ 一による解析結果を示す. 内層には $\mathrm{Fe}$ が少なく, $\mathrm{Ni}, \mathrm{Cr}$, $\mathrm{Si}$ が濃縮していて外層はFe および酸素より成ることがわ かる. これらの量的関係を判然とさすために line scan を 行なった. その結果を Photo.5 に示す. 地金の Cr 量より む内層のそれの方が多くなっており, 内外層の組成が明ら かである.

\section{5. 空気酸化と水蒸気酸化}

空気酸化と水蒸気酸化を比較するために $650^{\circ} \mathrm{C} \times 1000 \mathrm{hr}$ の試験を行なった結果を Table 3 に示す。これより水蒸 気酸化速度は空気酸化の 10 20倍もの值を示していてそ の機構にかなりの差があることがわかる。 


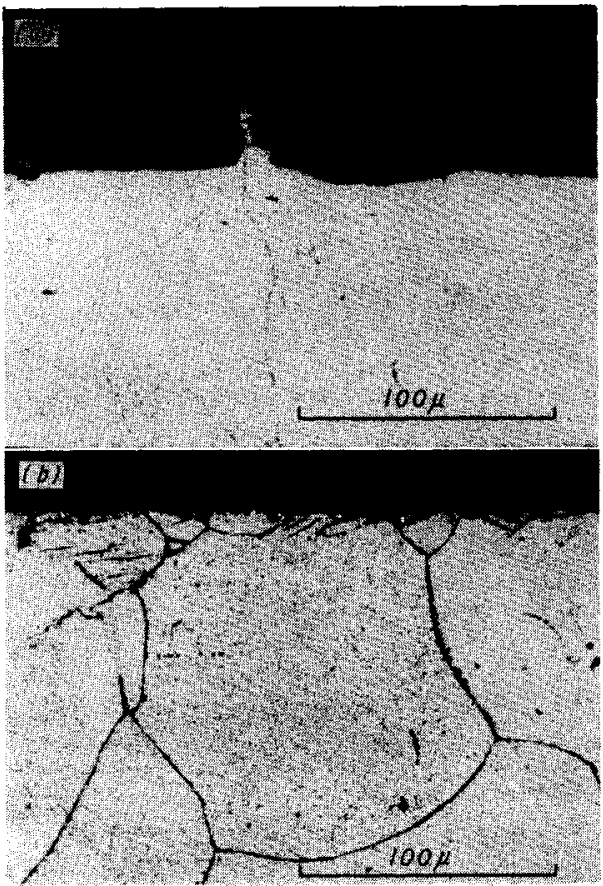

Photo.2 Effect of surface preparation on oxidation in steam of type 304 stainless steel at $650^{\circ} \mathrm{C}$ for $500 \mathrm{hr}$

(a) Acid pickled specimen

(b) Ground specimen

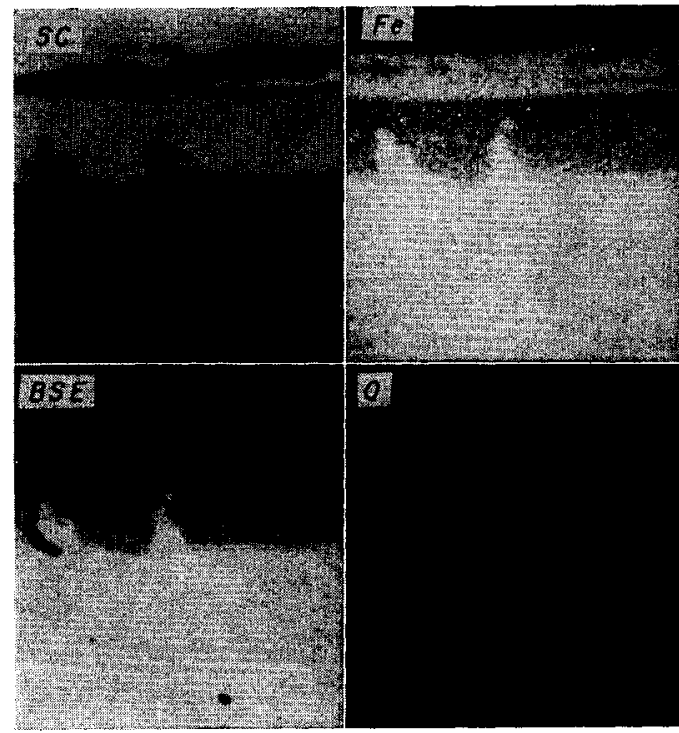

Photo.4 Segregation of elements in scale of type 304 stainless steel formed by oxidation in steam at $600^{\circ} \mathrm{C}$ for $1000 \mathrm{hr}$

\section{IV. 考察}

オーステナイト系ステンレス鋼の水蒸気による酸化スケ 一ルは Photo. 1,3，4 に示すよ5に一般に 2 層構造をなし ている，すなわち外層はへマタイトとマグネタイトより成 り，内層は $\mathrm{Fe}, \mathrm{Ni}, \mathrm{Cr}$ 含さスピネル型酸化物上り成っ ている。そして両層の境界は試験前の試験片表面に相当し

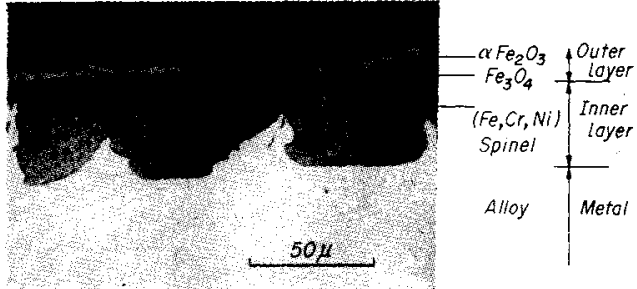

Photo.3 Microscopic structure of scale formed by oxidation in steam at $600^{\circ} \mathrm{C}$ for $1000 \mathrm{hr}$ (Type 304 stainless steel)

ていて，水袮気酸化はその面にまずクローム酸化物が生成 し，その欠宿を鉄が搪散して酸化し外置を形成する，一方 酸素は内部に执散して内層を形成する。この考え方は低炭 素銅に対し Potter(9)らが示し，ステンレス銅に対しては Warzee ${ }^{(5)}$ らが述べている見解と一致するものである。そ して内層の厚さを測定することにより，部分的に㔀離して いる外㥜の厚さを推定することができる(8).

実際のボイラの場合 ${ }^{(10)}$ ，往々にしてへマタイトが見ら れないでマグネタイトとスピネルのみの 2 層構造の場合が あるが，これは水蒸気中に含まれる酸素が非常に少ない場 合におこる現象である。

Fig. 2 に示した水蒸気酸化の時間的変化の湘定結果よ り，初期は直線的に急激な酸化が進行するが，ある時間以 後は酸化速度が著しく減少する。これは繳密な内層の形成

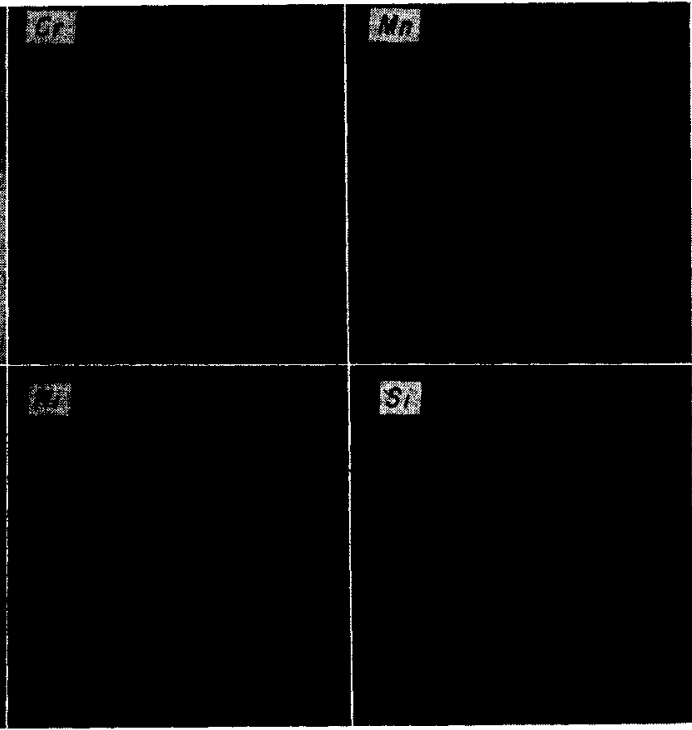

により酸化抵沉が增大するため，内層が厚くなるほど酸化 速度が減少することを意味する，図に扎いてあたか子水蒸 気酸化傾向が鋼種により異なるかのように見えるが, Fig.5

(9) E.C.Potter and G.M.W. Mann : Proc. 1st International Congress on Metallic Corrosion, London, (1962), 417.

(10) 野口: 火力発電, $21(1970), 432$. 


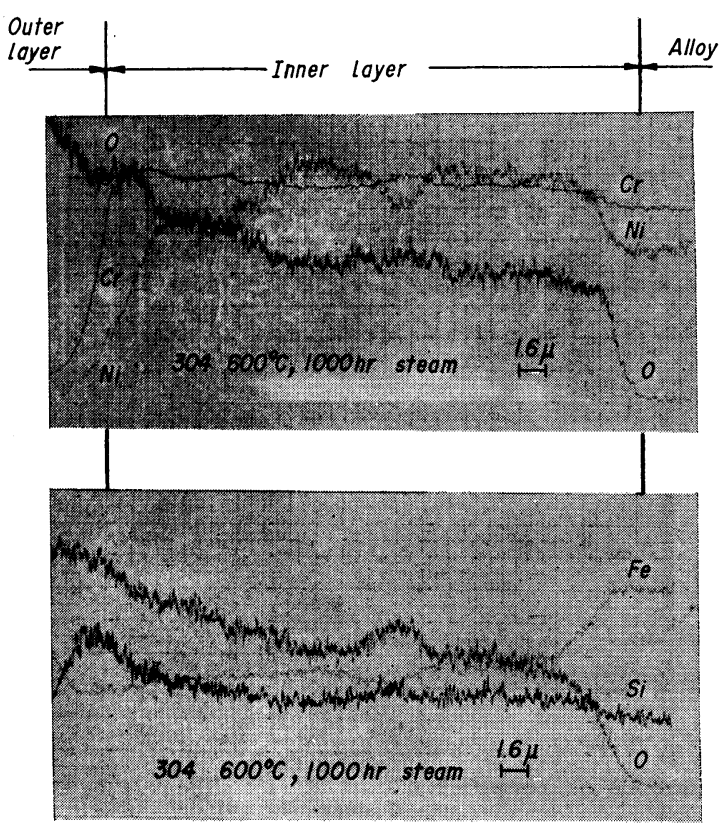

Photo.5 Line scan across inner scale of type 304 stainless steel formed by oxidation in steam at $600^{\circ} \mathrm{C}$ for $1000 \mathrm{hr}$

Table 3 Weight loss of commercial stainless steels by oxidation in steam and air at $650^{\circ} \mathrm{C}$ for $1000 \mathrm{hr}\left(\mathrm{mg} / \mathrm{cm}^{2}\right)$

\begin{tabular}{c|c|c|c|c|c|c}
\hline \hline $\begin{array}{c}\text { Atmosphare } \\
\text { Steel Run }\end{array}$ & \multicolumn{3}{|c|}{ In air } & \multicolumn{3}{c}{ In steam } \\
\cline { 2 - 7 } & 1 & 2 & Avr. & 1 & 2 & Avr. \\
\hline $304 \mathrm{H}$ & 0.51 & 0.53 & 0.52 & 11.05 & 10.34 & 10.70 \\
$316 \mathrm{H}$ & 0.75 & 0.73 & 0.74 & 18.69 & 16.52 & 17.61 \\
$321 \mathrm{H}$ & 0.51 & 0.55 & 0.53 & 10.28 & 9.92 & 10.10 \\
$347 \mathrm{H}$ & 0.54 & 0.62 & 0.58 & 5.75 & 5.43 & 5.59 \\
\hline
\end{tabular}

に結晶粒度の影響を示したように鋼種の違いによるのでは なく，むしろ結晶粒度の差によると考えられる．鋼種によ る水蒸気酸化性の差異があるように報告 ${ }^{(11)}$ されているが, このように，結晶粒度の影響の大きいことを考慮していな い. 結晶粒界は粒内に比較して，水蒸気酸化がおくれてい る.このことは結晶粒界へのクロムの搪散が早く(12), 初期 に界面に $\mathrm{Cr}_{2} \mathrm{O}_{3}$ が形成され，その保護性のために粒界酸化 がおさえられる.こう考えることにより水蒸気酸化の結晶 粒度依存性が理解でさる。

Fig. 5 に示されている現用 316,321 鋼のように結晶粒度 がほぼ等しく5.8〜6.0の場合の水蒸気酸化性の差異は合 金元素の影響を示していると考えられる.すなわち著者 ${ }^{(13)}$ らの研究の結果からも明らかなよらに，合金元素としての Cr は著しく耐水蒸気酸化性に有効である. したがって， Table 1 よりわかるように現用 316 鋼は 321 鋼に比較して Cr 含有量が約 $1 \%$ 程度少なくなっている．このように両 鋼種の差は Mo よりむしろ Cr 量の差によるためと考えら れる.
水蒸気酸化の温度依存性は Fig. 3 より明らかなように $650^{\circ} \mathrm{C}$ で急激に酸化減量が増大する。これについては更に 研究を行なっているので後報にゆずるが, この温度の上下 で, 水蒸気酸化の活性化エネルギーの差があるようであ $ろ^{(14)}$.

外層と内層はほぼ同じ厚さだけ成長すると考えられるの で(8) Fig.6に示すよらな残留スケール量を測定し, 水蒸気 酸化量と䟝離性の関係を明らかにすることができた。すな わち, 䟝離性は鋼種による差よりもむしろ生成スケール量 に依存し，スケールがある程度以上成長すると䟝離するよ らになる。 そして, そのスケール生成量は Fig. 5 に示すよ らに結晶粒度の大小に関係するので, 結晶粒度の小さいも のほどスケールの生成量も少なく，したがって䟝離もおこ りにくくなると考えられる. このことはボイラ過熱器管の トラブル防止対策上に重要な事であると考える.

表面仕上げの影響は Table 2 に示したよらに，水蒸気酸 化に対してグラインダー研摩は非常に有効な手段である. これは加工によりクロームの拡散が促進され(15) 初期に耐 食的なクローム酸化物が急速に形成されるためと考えられ る. Ruther(2)らはスケール中の合金元素を分析し，クロー ムが著しく多いことを示している．したがって水蒸気酸化 防止対策の一つとして過熱器管の内面を研摩して耐水蒸気 酸化性を増すことも考えられるが，加工の影響がどの位持 続するか，また残留応力が高くなることによる応力腐食割 れ感受性が増大寸るなど検討の余地がある.

空気酸化に比較して水蒸気酸化は約 $10 \sim 20$ 倍も大きい ことが Table 3 に示されている. Le May(16) は水蒸気酸化 の場合は生成する $\mathrm{Cr}_{2} \mathrm{O}_{3}$ が水に溶解して運び去られるため に酸化がはげしく進行するようになると述べているが，著 者らも実験装置の試験室とコンデンサーの中間に緑色の薄 いフィルムが生成することを経験しているので $\mathrm{Cr}_{2} \mathrm{O}_{3}$ の溶 解がおこっているものと考光, 水蒸気酸化の大きい理由と している.

\section{V. 結 言}

オーステナイト系ステンレス鋼の高温水蒸気酸化に関す る実験を行なった結果つぎのような結論を得た。

（1）水蒸気酸化の時間的変化を測定した結果，初期の急 激な酸化減量につついて著しく酸化速度が減少する.

（2）水蒸気酸化の温度依存性をみると, $650^{\circ} \mathrm{C}$ より急激 に酸化が進行するようである.

(11) W.Stiefel : Sulzer Technical Review, 3 (1961), 21.

(12) W.B.A. Sharp: Proc. 4th International Congress on Metallic Corrosion, Amsterdam, (1969), 63.

（13）小若,諸石, 永田 : 1971 年 10 月本会秋期大会 (金沢) に発表.

(14) 小若, 諸石 : unpublished.

(15) T.Ericsson and R.Roseen : 5 th International Congress on $X$-ray optics and microanalysis, New Yonk, (1969)

(16) I. Le May : Proc. 3rd International Congress on Metallic Corrosion, Moscow, (1966) , 375. 
(3) 現用鋼の5ちでは 347 鋼が最もすぐれて打り，316 鋼が劣り，304，321 鋼がその中間になる.

（4）水蒸気酸化は結晶粒度俵存性が大きく，粒度が小さ くなるほど(ASTM No.が大きくなる)直線的に減少する。 現用 347 鋼がすぐれているのは結晶粒度が小さいことが寄 与していると考㝋られる。究して粒界に打ける $\mathrm{Cr}$ の拻散 が早いためと考えられる。

（5）スケール付着率は水蒸気酸化量火 依存し, 約 $30 \mu$
位の厚さに成長すると外層が影離する.

（6）水蒸気酸化に対する表面仕上げの影響としてはグラ インダー研摩が有效である。

(7) 水蒸気酸化は空気酸化に比較して $10 \sim 20$ 倍の酸化 量となる。

（8）スケールは外層と内層にわかれ，前者は鉄酸化物を 主体とするへマタイトおよびマグネタイトより成り，後者 は $\mathrm{Fe}, \mathrm{Ni} ， \mathrm{Cr}$ を含むスピネル構造をしている。 